\title{
Lung hydatid cysts
}

\author{
Mehrnaz Asadi Gharabaghi, ${ }^{1}$ Niloofar Ayoobi Yazdi, ${ }^{2}$ Sirous Jafari ${ }^{3}$ \\ ${ }^{1}$ Department of Pulmonary Medicine, Tehran University of Medical Sciences, Tehran, Islamic Republic of Iran \\ ${ }^{2}$ Department of Radiology, Tehran University of Medical Sciences, Tehran, Islamic Republic of Iran \\ ${ }^{3}$ Department of Infectious Diseases, Tehran University of Medical Sciences, Tehran, Islamic Republic of Iran
}

Correspondence to Dr Mehrnaz Asadi Gharabaghi, asadi m@tums.ac.ir

\section{DESCRIPTION}

A 36-year-old, otherwise healthy man presented with a 3 -week history of dry cough. He had no other symptom such as dyspnoea, chest pain, fever, and anorexia or weight loss. He was an employee in an urban post office but recalled exposure to domestic animals in a rural area in previous months.

On physical examination, he was reasonably well. There were coarse inspiratory crackles over both lungs; otherwise, the rest of the exam was normal.

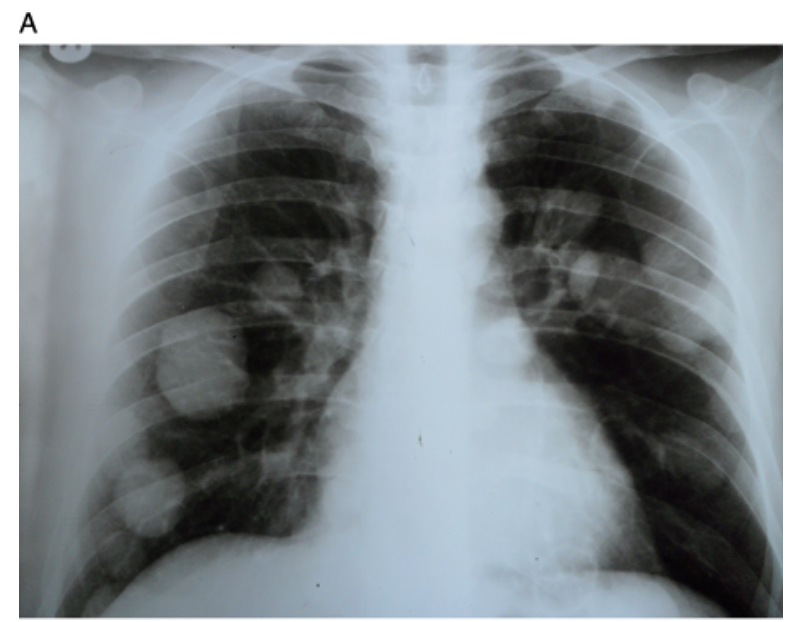

B

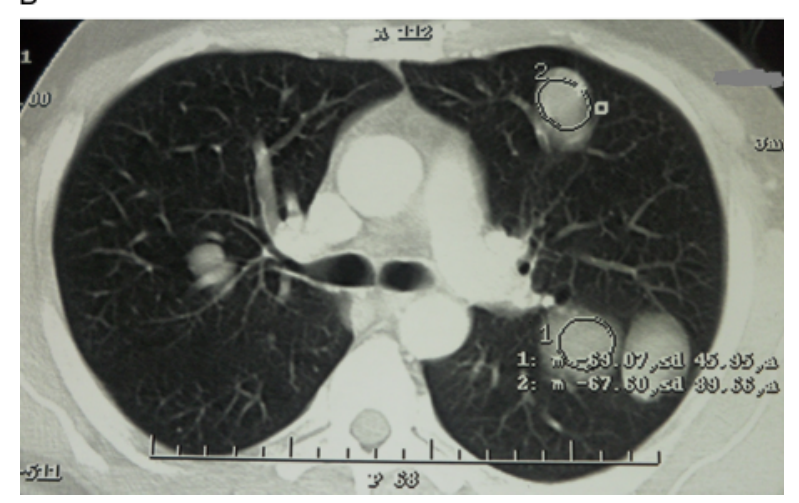

Figure 1 (A, B) Chest radiography and a section of CT scanning of thorax illustrating multiple well-circumscribed masses of variable sizes over both lungs.
Chest radiography showed multiple well-demarcated mass-like lesions over both lungs (figure 1A). CT scanning of lungs showed multiple well demarcated round and homogenous masses of variable size over both lungs (figure 1B). Based on patient's history, mild blood eosinophilia, strong positivity for Echinococcus IgG and imaging data, multi-focal lung hydatidosis was the most probable diagnosis. Abdominopelvic CT scanning also revealed multiple cysts over the liver, spleen and pancreas (figure 2). There was no evidence of hydatid cysts on the brain or cardiac imaging. Due to the extent of disease, surgical resection was not reasonable. Therefore, he was treated by a 2-year regimen of albendazole and recommended to be followed-up on a regular base.

Lung hydatidosis is a parasitic infection caused by larval stage of Echinococcus granulosus. Uncomplicated cysts remain asymptomatic or produce subtle symptoms such as cough. Liver and lung are the most common sites of infection. Multi-organ involvement has also been reported. ${ }^{1}{ }^{2}$ Surgical resection is the treatment of choice; however, when surgery is not feasible due to obstacles such as extent of disease, a 2-year imidazole-based regimen is opted. ${ }^{3}$

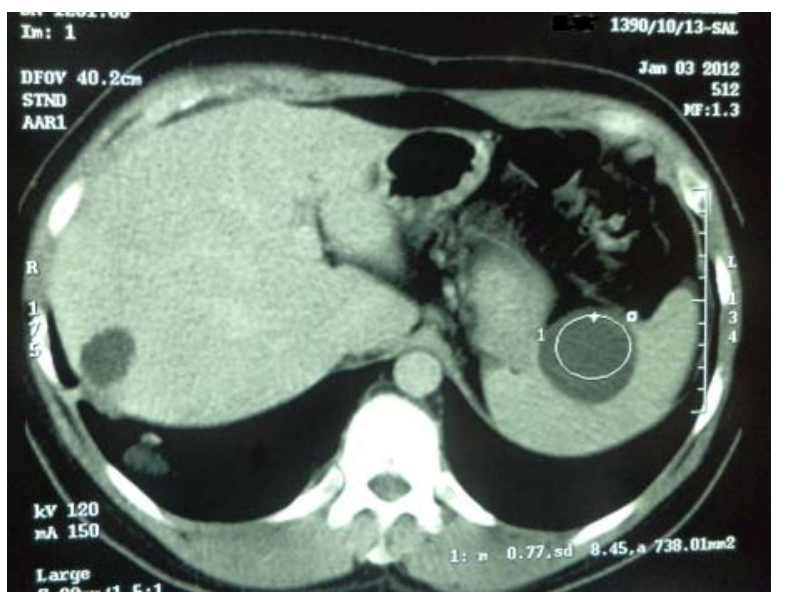

Figure 2 A section of CT scanning of the abdomen illustrating the cysts over liver and spleen. 


\section{BMJ Case Reports}

\section{Learning points}

- Pulmonary hydatidosis must be considered in differential diagnosis of multiple well-shaped cystic lesions of the lung.

- Pulmonary hydatidosis may be associated with multi-organ involvement of hydatid cyst.

- Lung hydatidosis is not confined to rural areas and habitants of urban areas may develop the disease upon exposure to domestic animals primarily dog feces or contaminated food and water.
Competing interests None.

Patient consent Obtained.

\section{REFERENCES}

1. Madan K, Singh N. Bronchoscopic diagnosis of pulmonary hydatid cyst. Can Med Assoc J 2012;184:E158.

2. Tor M, Atasalihi A, Altuntas N, et al. Review of cases with cystic hydatid lung disease in a tertiary referral hospital located in an endemic region: a 10 years' experience. Respiration 2000;67:539-42.

3. Bozbuga N, Erentug V, Akinci $E$, et al. Is surgical therapy the only treatment of choice for cardiac echinococcosis with multiple organ involvement? Interact Cardiovasc Thorac Surg 2003;2:367-8.

This pdf has been created automatically from the final edited text and images.

Copyright 2012 BMJ Publishing Group. All rights reserved. For permission to reuse any of this content visit http://group.bmj.com/group/rights-licensing/permissions.

BMJ Case Report Fellows may re-use this article for personal use and teaching without any further permission.

Please cite this article as follows (you will need to access the article online to obtain the date of publication).

Asadi Gharabaghi M, Ayoobi Yazdi N, Jafari S. Lung hydatid cysts. BMJ Case Reports 2012;10.1136/bcr-2012-006551, Published XXX

Become a Fellow of BMJ Case Reports today and you can:

- Submit as many cases as you like

- Enjoy fast sympathetic peer review and rapid publication of accepted articles

- Access all the published articles

- Re-use any of the published material for personal use and teaching without further permission

For information on Institutional Fellowships contact consortiasales@bmjgroup.com

Visit casereports.bmj.com for more articles like this and to become a Fellow 